\title{
BioLink
}

Jurnal Biologi Lingkungan, Industri, Kesehatan

Available online http://ojs.uma.ac.id/index.php/biolink

\section{ISOLATION, IDENTIFICATION, AND METAL RESISTANCE TESTING OF SOIL FUNGI (RHIZOSPHERE) FROM BANGKA TIN POST-MINING}

\author{
Mutiara Darlingga1, Rahmad Lingga ${ }^{1 *}$, \& Andri Kurniawan² \\ ${ }^{1}$ Department of Biology, Faculty of Agriculture, Fisheries and Biology, Universitas Bangka \\ Belitung, Indonesia \\ 2Department of Aquaculture, Universitas Bangka Belitung, Indonesia
}

Submited : 09-07-2021; Reviewed : 27-08-2021; Accepted : 04-01-2022

*Corresponding author: E-mail : linkgarahmad@gmail.com

\begin{abstract}
The ecological impacts of tin mining activities in the Bangka island is the presence of heavy metal contamination that accumulated in the environment. One of the heavy metals that was often found in posttin mining areas is lead (Pb). Mycoremediation is a method that can be used to reduce lead pollution in post-tin mining areas. This study aimedto isolate, resistance test and identify to Pb-resistant soil fungi (rhizosphere) in the post-tin area of Bangka. The research methods included isolation, test of fungal resistance to $\mathrm{Pb}$ metal (Control, 150ppm, 250ppm, 350ppm, 500ppm, 1,000ppm, 5,000ppm and 10,000ppm), macroscopic and microscopic identification. The results showed that 9 isolates tested, there were 6 isolates that were resistant to $\mathrm{Pb}$ up to the concentration of 5,000 ppm, namely isolates I1(Rhizoctonia), I2(Penicillium sp1), I5(Papulaspora), I6(Penicillium sp2), I7(Penicillium sp3) and I9 (Sclerotium). Three isolates of soil fungus were not resistant to $\mathrm{Pb}$ up to a concentration of 5,000 ppm, namely isolates I4 (Sclerotium), I8(Microsporum), and I10(Cladosporium). All isolates did not grow anymore at a concentration of 10,000 ppm of $\mathrm{Pb}$.
\end{abstract}

Keywords: Micoremediation; Pb metal,; Resistance; Soil fungi; Tin mining

How to Cite: Darlingga, M., Lingga, R., \& Kurniawan, A. (2022). Isolation, Identification, And Metal Resistance Testing of Soil Fungi (Rhizosphere) From Bangka Tin Post-Mining, BioLink: Jurnal Biologi Lingkungan, Industri dan Kesehatan, Vol. 8 (2): Hal. 180-194 


\section{INTRODUCTION}

Tin mining activities on Bangka island have an ecological impact on the environment. The negative impacts that appear on the land around mining are the increase in critical land due to reduced forest area, the loss of germ plasm due to the loss of forest ecosystems and habitats for animals, causing the environment to be below quality standards due to decreasing soil quality (Suryati, 2017; Kurniawan \& Mustikasari, 2019). Another negative impact caused by tin mining is the presence of heavy metal contamination that accumulates in the environment (Kurniawan \& Mustikasari, 2019). One of the heavy metals that is often found in posttin mining areas in Bangka Belitung is lead $(\mathrm{Pb})$. Several studies have shown that the concentration of lead heavy metal contamination in post-tin mining areas is much higher than other metals such as $\mathrm{Cr}$, $\mathrm{As}, \mathrm{Cu}$ and $\mathrm{Cd}$. The results of study by Kurniawan et al., (2019) showed that the concentration of lead metal in post-mining land was 4.62-8.21 ppm.

Heavy metal lead that accumulates in the environment can cause a decrease in microbial activity, soil fertility and quality, as well as the entry of lead metal into the body of organisms. Lead accumulation that exceeds the tolerance limit has a toxic effect on an organism, 2011). The lead enters the body of organisms through the food chain and then forms food webs and ends up in humans as the highest level of consumers. The accumulation of lead in humans can cause dangerous diseases and even death. The impact of lead on humans is that it can damage body organs, especially the nervous system, blood formation system, kidneys, heart system and reproductive system. Lead can also cause anemia, hypertension, impaired blood synthesis, hyperactivity, brain damage and liver disease (Amaral et al., 2010).

One of the efforts that can be done to reduce lead pollution in post-tin mining areas is to use the microremediation method. Mycoremediation is a detoxification process for toxic materials from a polluted environment using fungi (Asiriuwa et al., 2013). Microremediation can be done by multiplying the fungus (biostimulation) that is already in the polluted soil by providing the necessary growth environment and increasing the fungal population (bioaugmentation) (Ahmad, 2018). The microremediation mechanism consists of separation of cellular extracts through chelation and cell wall binding and physical intracellular separation of metals through binding of proteins or other ligands in order to 
prevent damage to metal sensitive cellular targets.

Fungi isolated from an environment contaminated with heavy metals are very potential to be used as bioremediation agents, because these fungi have resistance and tolerance for heavy metals in the surrounding environment (Ahmad, 2018). Research on the isolation of fungi that have resistance to lead found in post-tin mining areas in Bangka has never been done before. This research needs to be carried out to obtain the type of fungus that is resistant to lead, so that it can be used as a candidate for microremediator in post-tin mining fields through the identification and resistance test process.

\section{MATERIALS AND METHODS}

The research was carried out from November 2020 to March 2021. The sampling location was carried out in Bangka post-tin mining (Figure 1). Samples were taken from the soil around the roots for fungal isolation and measurement of $\mathrm{Pb}$. Isolation of fungi in soil samples was carried out at the Microbiology Laboratory, Faculty of Agriculture, Fisheries and Biology, Bangka Belitung University. Tests for $\mathrm{Pb}$ levels were carried out by the Chemical Laboratory, PT. Timah Tbk. Identification of the fungus was carried out at Microbiology, Faculty of Agriculture,
Fisheries and Biology, Bangka Belitung University and Fish Quarantine Station, Quality Control and Safety of Fishery Products in Pangkalpinang.

The main object of this research project is a soil sample taken from Bangka Tin Post Mining. The materials used include distilled water, 70\% alcohol, Bengal Rose Agar, HCL 37\%, HNO3 65\%, PDA (Potato Dextrose Agar) media, $0.9 \% \mathrm{NaCl}, \mathrm{Pb}$ nitrate $(\mathrm{Pb}(\mathrm{NO}))$, and paper, strain. The tools used in this research include autoclave, soil drill, petri dish, incubator, caliper, Laminar Air Flow Cabinet (LAFC), microscope, and vortex.

\section{Research Sampling}

The sampling method was carried out by purposive sampling by considering the presence of plants in post-mining area. The plants used were Australian pine (Casuarina equisetifolia). Sampling was carried out at three stations S1, S2 and S3 with each point originating from one plant. Soil was taken from each 1 point of collection with a soil depth of $\pm 20 \mathrm{~cm}$ (Edhar et al., 2017).

\section{Fungal Isolation and Purification}

Isolation of the fungus was carried out using the dual pour cup method on Rose Bengal Agar media up to a dilution of 10-5. Samples from the 10-3, 10-4, and 10-5 dilutions as much as $100 \mathrm{~L}$ were inoculated into Rose Bengal Agar media and the 
inoculation results were then incubated at room temperature $26^{\circ} \mathrm{C}-28^{\circ} \mathrm{C}$ for 7 days. The fungal isolates that grew were then calculated for their population using the Total Plate Number (ALT) calculation formula (Wijaya, 2018). The fungal isolates that grew were selected Based on macroscopic morphological differences (colonial shape, colony color front view, colony color rear view, surface texture, presence or absence of mycelium) and then inoculated back into new media (Ed-har et al., 2017).

\section{Fungal Resistance Ability Test}

The fungal isolate resistance test was carried out in two stages, namely qualitative and quantitative tests. Qualitative tests were carried out by inoculating fungal isolates on media that had added $\mathrm{Pb}$ with concentrations of 150 , $250,350,500,1,000,5,000$, and 10,000 $\mathrm{ppm}$, then incubated at room temperature $26^{\circ} \mathrm{C}-28^{\circ} \mathrm{C}$ for 7 days. Qualitative tests were carried out to see whether the fungus grew or not on media with the addition of metal. Quantitative test to see the growth of the fungus through the diameter of the isolate colonies. The increase in the colony diameter of the isolates was measured daily using a caliper. The results of fungal growth on agar media with heavy metals were compared with control media without the addition of heavy metals (Rose \& Devy, 2018).

\section{Identification of Fungal Isolates}

Microscopic characterization of isolates (hyphal shape, hyphal branching, presence or absence of septa, presence or absence of conidia, conidia form) was carried out by direct observation of fungal isolates on a slide in a microscope with 1000x magnification (Ed-har et al., 2017). The identification process was carried out by comparing the morphological characters of the isolates both macroscopically and microscopically with the identification book Identifying Filamentous Fungi: Pictorial Atlas of Soil and Seed Fungi Morphologies of Cultured Fungi and Key to Species: Third Edition (Watanabe, 2010).

\section{Data analysis}

The research data obtained were analyzed descriptively. Data types and growth ratio values are displayed in the form of tables and graphs using Microsoft Office 2007.

\section{RESULTS AND DISCUSSION}

Isolation of Fungi (Rhizosphere) from Tin Post Mining

The highest number of fungal populations (rhizosphere) was at Station 1 with a total of $5.7 \times 104 \mathrm{CFU} / \mathrm{g}$ and the 
lowest number of fungi was at Point 3 with a total of $0.9 \times 104 \mathrm{CFU} / \mathrm{g}$ (Table 1). The results of the isolation of the fungus (rhizosphere) on Rose Bengal media obtained 10 isolates of fungi with different macroscopic characteristics. The fungal isolates found in Station 1 were 6 isolates (I1, I2, I5, I6, I7, I8), Station 2 found 2 isolates (I3, I4), and Station 3 found 2 isolates (I9, I10) (Figure 1) . The number of fungal isolates (rhizosphere) that were successfully purified in Rose Bengal media amounted to 9 isolates, namely isolates I1, I2, I4, I5, I6, I7, I8, I9, and I10, while 1 other isolate, isolate I3 died during purification.

Table 1. Number of fungi (rhizosphere) in post-mining

\begin{tabular}{cc}
\hline Station & Total fungal population (CFU/g) \\
\hline 1 & $5.7 \times 104$ \\
2 & $0.9 \times 104$ \\
3 & $2.3 \times 104$ \\
\hline
\end{tabular}
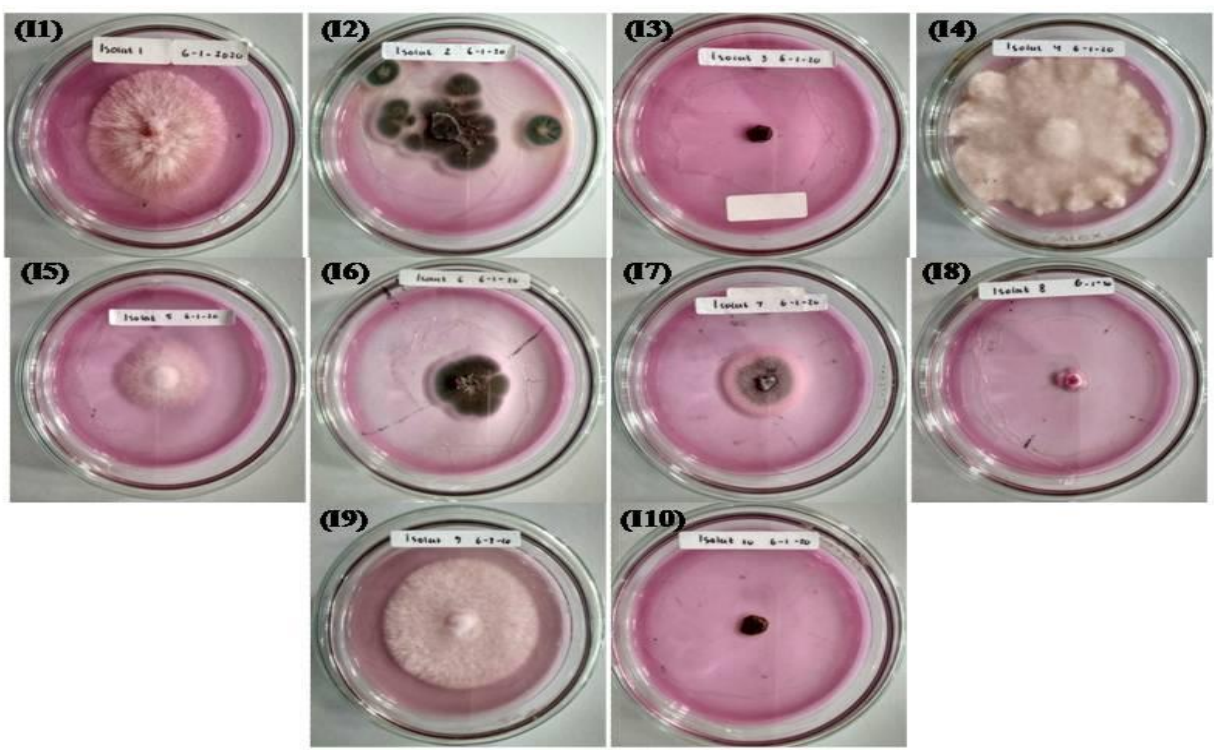

Figure 1. Fungal (rhizosphere) isolates from post-tin mining on Rose Bengal agar media 7th day of incubation

Fungal Resistance Ability Test isolates I1, I2, I5, I6, I7 and 19. The other

\section{(Rhizosphere)}

The results of the resistance test against 9 isolates of fungi (rhizosphere) showed that 6 (six) isolates of fungi (rhizosphere) were resistant to $\mathrm{Pb}$ up to a concentration of 5,000 ppm, namely three isolates of fungi (rhizosphere) were not resistant at a concentration of 5,000 ppm, namely isolates I4, I8, and I10. The results of further research showed that all isolates did not grow again at a concentration of 10,000 ppm (Table 2). 
Table 2. Test of resistance of the fungus (rhizosphere) to $\mathrm{Pb}$. metal

\begin{tabular}{ccccccccc}
\hline $\begin{array}{c}\text { Isolation } \\
\text { Code }\end{array}$ & \multicolumn{7}{c}{ Pb. metal concentration } \\
\cline { 2 - 8 } & $\mathbf{1 5 0} \mathbf{~ p p m}$ & $\mathbf{2 5 0} \mathbf{~ p p m}$ & $\mathbf{3 5 0} \mathbf{~ p p m}$ & $\mathbf{5 0 0} \mathbf{~ p p m}$ & $\mathbf{1 0 0 0} \mathbf{p p m}$ & $\begin{array}{c}\mathbf{5 , 0 0 0} \\
\text { ppm }\end{array}$ & $\mathbf{1 0 , 0 0 0} \mathbf{~ p p m}$ \\
\hline I1 & + & + & + & + & + & + & - \\
I2 & + & + & + & + & + & + & - \\
I4 & + & + & + & + & + & - & - \\
I5 & + & + & + & + & + & + & - \\
I6 & + & + & + & + & + & + & - \\
I7 & + & + & + & + & + & + & - \\
I8 & + & + & + & + & + & - & - \\
I9 & + & + & + & + & + & + & - \\
I10 & + & + & + & + & + & - & - \\
\hline
\end{tabular}

Description: +(resistance) -(not resistant)

Heavy metal resistance is one of the

concentration of $10,000 \mathrm{ppm}$ all isolates abilities of microorganisms to develop did not grow again (Table 2). These resistance to toxic heavy metal ions. The isolates were able to be resistant to certain resistance test was carried out through 8 concentrations of lead, namely Control (0), metal concentrations due to the ability or $150,250,350,500,1,000,5,000$, and resistance to metals which allowed the 10,000 ppm. The provision of different concentrations refers to previous research, namely Wijaya's research, (2018) which showed that from concentrations of 150 , fungus to be able to live in media with the addition of heavy metal $\mathrm{Pb}$. It is supported by the statement of Anahid et al., (2011), which stated that the ability of fungal isolates to be resistant in the environment 250 and $400 \mathrm{ppm}$, the optimal with the addition of metals was due to the concentration for the resistance test was in the range of $250 \mathrm{ppm}$, so the concentrations of $150,250,350,500$, 1,000, 5,000 and 10,000 ppm.

The results of the resistance test to 9 isolates of fungi (rhizosphere) showed 6 (six) isolates of fungi (rhizosphere) were resistant to $\mathrm{Pb}$ up to a concentration of 5,000 ppm, namely isolates I1, I2, I5, I6, I7 and I9, 3 (three) isolates of fungi ability of these isolates to survive by adapting to high concentrations of toxic heavy metals. Several other isolates were not resistant due to the different ability of the isolates in the process of the resistance mechanism to these metals. Based on Iram et al., (2013), differences in metal resistance are caused by the various strategies of different resistance mechanisms shown by the fungus. (rhizosphere) not resistant at a The ability to survive at concentration of 5,000 ppm, namely concentrations of toxic heavy metals in the isolates I4, I8, and I10, and at a fungus (rhizosphere) is better known as 
the resistance of the fungus. The resistance mechanism serves to overcome the toxicity of heavy metals so as not to interfere with the biological function of microorganisms (Anahid et al., 2011). The ability of fungal resistance occurs through two mechanisms, namely the extracellular mechanism and the intracellular mechanism (Ahmad, 2018). The extracellular mechanism functions to prevent the cell from entering metal, while the intracellular mechanism functions to reduce the metal load in the cytosol (Anahid et al., 2011).

The extracellular mechanism occurs through biosorption and chelation formation, while the intracellular mechanism occurs through efflux pumps, production of metallothionein and phytochelatin proteins, and vacuole compartmentalization (Lotlikar, 2019). Biosorption is a process of passive absorption of metals by microorganism cells, resulting from the formation of metal-complex organics with microorganism cell walls, capsules or extracellular polymers that are synthesized and excreted by microorganisms (Ahmad, 2018). The formation of chelate is the formation of a double coordination bond between organic and metal molecules which functions for the natural detoxification process of heavy metals (Anahid et al. 2011).

The efflux pump is a metal detoxification process where if the surface of living cells is saturated with metal species, the metal will penetrate into the interior of the cell through ion channels (Yang et al., 2016). Metallothionein protein is a metal-binding cytoplasmic protein that can modulate the concentration and intracellular binding of both essential metals such as $\mathrm{Cu}$ and $\mathrm{Zn}$ and non-essential metals such as $\mathrm{Cd}$. Phytokelatin protein is a cytoplasmic protein that functions as an intracellular chelator in fungal cells. Vacuoles in fungi have an important role in molecular degradation, storage of metabolites, regulation of cytosolic concentrations of metal ions and detoxification of potentially toxic metal ions (Siddiquee et al., 2015).

The growth of the fungus was indicated by the increase in isolate diameter per day. The fungal isolates that had the fastest growth were marked by the largest isolate diameter values at the 7 th day of incubation. The fastest growth of fungal isolates (rhizosphere) was at a concentration of $5,000 \mathrm{ppm}$ on the 7 th incubation day, indicated by isolate I9, which was $65.57 \mathrm{~mm}$, while the slowest growth was found by isolate I6, which was $11.25 \mathrm{~mm}$. The other five isolates, namely 186 
I1, I2, I4, I8 and I10 did not grow at a isolates (rhizosphere) at a concentration of concentration of 5,000 ppm. All fungal 10,000 ppm did not grow (Figure 2).

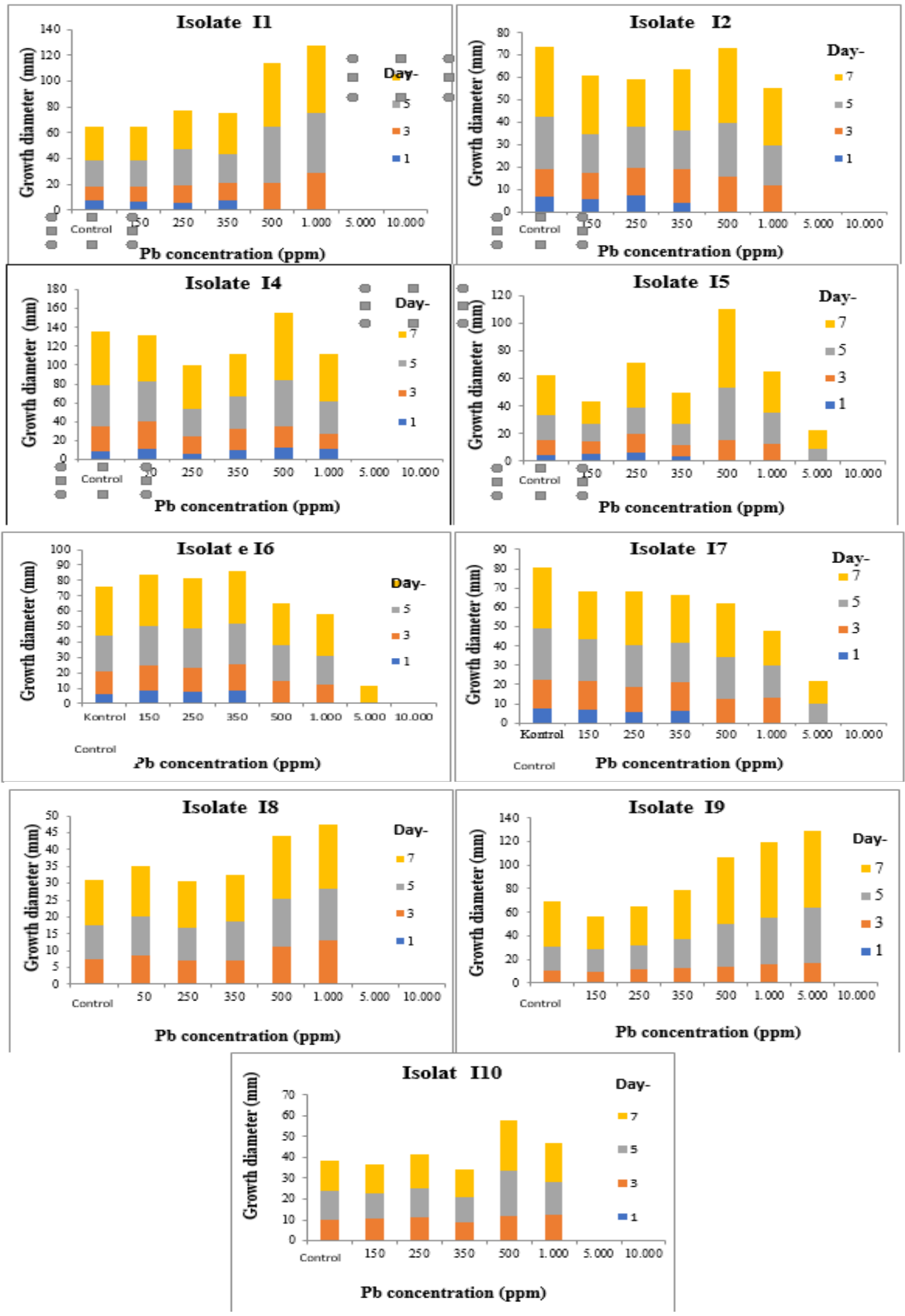

Figure 2. Growth graph of fungal isolates (rhizosphere) incubation days 1, 3, 5, and 7 
The fungal isolates that had the fastest growth were marked by the largest isolate diameter values at the 7 th day of incubation. The results showed that the isolate that had the fastest growth at a concentration of 5,000 ppm incubation on the 7 th day was indicated by isolate I9, which was $65.57 \mathrm{~mm}$ (Figure 2). The isolate, which belongs to the genus Sclerotium, is known to have the ability to be resistant to $\mathrm{Pb}$ metal (Sana et al., 2015). In addition, the genus Sclerotium also has a special structure in the form of sclerotia which allows it to live in the soil for how many years and in an unfavorable environment, one of which is polluted by heavy metals (Arunasri et al., 2011)

Some isolates had an increasing growth along with the increase in heavy metal concentrations and began to decrease from a concentration of 1,000 ppm to $10,000 \mathrm{ppm}$, such as isolates I8 and I9 (Figure 2). It was due to the contact with $\mathrm{Pb}$ metal, the fungus underwent morphological ultrastructural changes in the form of thicker mycelium with a larger diameter due to cell wall thickening. Cell wall thickening occurs due to changes in cell wall composition, namely an increase in hydroxyl proteins (Ekawati, 2019). Hydroxyl protein plays a role in the process of cell wall biosynthesis which affects the growth of fungal cells. The greater the concentration of hydroxyl protein in the cell wall, the greater the cell wall biosynthesis process, causing the growth of fungal cells to increase (Yanti et al., 2016).

Other isolates had slow growth as the metal concentration increased, and did not even grow at high concentrations such as $5,000 \mathrm{ppm}$ and $10,000 \mathrm{ppm}$. The growth of the fungus decreased from a concentration of $500 \mathrm{ppm}$ (Figure 2). The decrease in fungal growth at concentrations ranging from $500 \mathrm{ppm}$ was due to the concentration of metal being too high and so toxic to fungal cells. It is supported by Ahmad's statement (2018), that the decreased growth and stunted growth were caused by the concentration of $\mathrm{Pb}$ metal which was too high so that it was toxic to the fungus. Study by Amatussalam et al., (2014) also mentioned that the metal absorption process in fungi is optimal up to a concentration of 500 ppm, and is stable or decreases from a concentration of $1000 \mathrm{ppm}$.

Study by Aishwarya et al., (2017) showed that an increased concentration of heavy metals caused a decrease in fungal growth due to heavy metal toxicity. Metal toxicity occurs through the displacement of the essential metal from its original binding site or through ligand interactions. Heavy metal toxicity in fungi can damage cell membranes, change enzyme structures, 
disrupt cellular functions, and damage DNA structures (Olaniran et al., 2013). Changes in the morphology and metabolism of fungi caused by changes in the structure of nucleic acids can cause functional and cell membrane disorders, as well as inhibit enzyme activity and oxidative phosphorylation (Fashola et al., 2016). It is what causes the growth of the fungus to decrease and be hampered and even die. Based on Wijaya, (2018) metal levels that are too high can reduce or inhibit fungal growth.

Fungal isolates (rhizosphere) were said to be resistant if they were able to grow in media with the addition of $\mathrm{Pb}$ metal, and not resistant if they did not grow in media with the addition of $\mathrm{Pb}$ metal. The fungus (rhizosphere) that was resistant to $\mathrm{Pb}$ up to a concentration of $5,000 \mathrm{ppm}$ consisted of 6 isolates from the genus Rhizoctonia, Penicillium, Sclerotium and Papulaspora. The other three isolates from the Genus Sclerotium, Microsporum and Cladosporium were only able to withstand a concentration of 1,000 ppm. Resistant fungi are useful in remediating environments contaminated with heavy metals because these fungi are able to survive in polluted environments and several types of fungi can reduce levels and toxicity of heavy metals in the environment (Ahmad, 2018).

Several studies have shown that a number of fungal isolates are resistant to heavy metals because they have a special ability to bind, immobilize or reduce heavy metal toxicity in a polluted environment. The results showed that the Penicillium genus was able to withstand up to $5000 \mathrm{ppm} \mathrm{Pb}$ metal concentrations. It is supported by a statement that explains that the genus Penicillium is resistant to $\mathrm{Pb}$ up to a concentration of $3000 \mathrm{~g} / \mathrm{L}$ and is able to reduce $\mathrm{Pb}$ (II) up to 98.25 (Iram et al., 2013; Tian et al., 2018). The ability to absorb and reduce $\mathrm{Pb}(\mathrm{II})$ by the genus Penicillium is due to the mechanism of biosorption and bioaccumulation by fungi. Biosorption is one of the mechanisms that play an important role in the tolerance ability of fungi. Biosorption occurs passively and is an independent metabolic reaction between heavy metals and fungal cell walls. This cell wall serves as the first barrier against incoming heavy metals and reduces metal concentrations (Maini et al., 2019).

Research on the genus Sclerotium showed that the same two genera had the ability to resist $\mathrm{Pb}$ at different concentrations. The genus Sclerotium isolate I9 was able to withstand $\mathrm{Pb}$ metal 
up to a concentration of 5,000 ppm, while the other isolate, isolate I4 was only able to withstand $\mathrm{Pb}$ metal up to a concentration of $1,000 \mathrm{ppm}$. It was due to the possibility that the two isolates were from the same genus but different species. The difference in metal resistance is caused by the existence of various strategies of different resistance mechanisms shown by different fungal species (Iram et al., 2013). Study by Sana et al., (2015) showed that Sclerotium rolfsii was able to tolerate $\mathrm{Cr}$ (III) up to a concentration of $100 \mathrm{ppm}$.

The genus Rhizoctonia and Papulaspora are also capable of being resistant to $\mathrm{Pb}$ up to a concentration of 5,000 ppm. Research by Kredics et al., (2001) showed that the genus Rhizoctonia was resistant to $\mathrm{Pb}$. metal. Two other genera such as the genus Cladosporium and Microsporum were only able to withstand $\mathrm{Pb}$ metal up to a concentration of 1000 ppm. Study by Rossiana et al.,
(2015) showed that Cladosporium can reduce lead levels by $17.94 \%$ in 60 days of incubation. Research by Calvillo-Medina et al., (2020) showed that the genus Cladosporium was psychrotolerant, pigmented and resistant to different concentrations of $\mathrm{Pb}(\mathrm{II})$.

\section{Identification of Fungal Isolates}

Based on the results of macroscopic and microscopic identification, the identity of the fungus (rhizosphere) was obtained, namely I1 is the genus Rhizoctonia. Isolates I2, I6, and I7 were of the genus Penicillium. Isolates I4 and I9 were of the genus Sclerotium. Isolate I5 was the genus Papulaspora. I8 isolate was the genus Microsporum. I10 isolate was the genus Cladosporium. The results of observations of microscopic and macroscopic characteristics are shown in Table 3 . Characteristics of fungal isolates (rhizosphere) at a magnification of $10,000 \mathrm{x}$ are shown in Figure 3. 

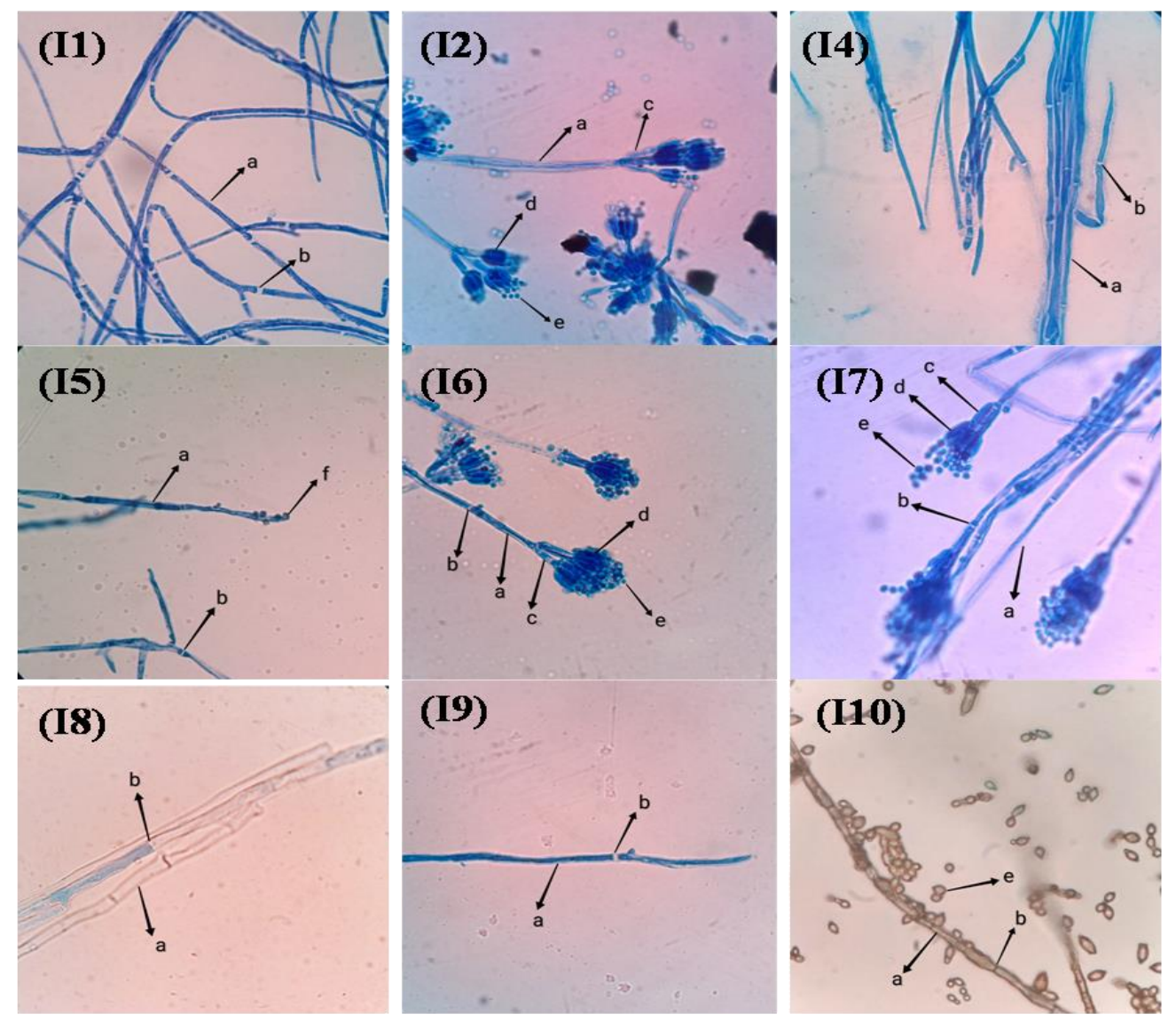

Figure 3. Microscopic characterization of fungal isolates (rhizosphere) at 1000x magnification of 7th day incubation, a) hyphae; b) septa; c) fialid; d) metula; e) conidia; f) papules.

The identification of fungal isolates was based on the macroscopic and microscopic characteristics of the isolates and compared with the book Identification of Pictorial Atlas and Seed Fungi. The results of the macroscopic characteristics of the isolates showed that 4 isolates belonged to fungi that had spores, and 5 other isolates belonged to fungi that did not have spores or were sterile fungi. Based on the identification of 9 isolates of fungi that were resistant to $\mathrm{Pb}, 6$ genera of fungi were obtained, namely Sclerotium, Papulaspora,
Rhizoctonia, and Penicillium, Microsporum and Cladosporium.

The results of the characterization of fungal isolates showed that isolates I4 and I9 had similarities with the genus Sclerotium. The characteristics of the genus Sclerotium are that conidia are not formed, the hyphae are white, branched, with septate side branches and are limited very close to the main hyphae, sometimes with clamping connections in some isolates (Watanabe, 2010). Isolate I5 was similar to the genus Papulaspora. The characteristics of the Papulaspora genus are conidia not 
formed, papules in the form of globus or subglobus, papules are located in terminal or intercalary areas, hyphae are branched with septa (Watanabe, 2010). Isolate I1 was similar to the genus Rhizoctonia in that conidia were not formed, hyphae branched to form a right angle, bounded by septa between the main hyphae and side branches (Watanabe, 2010).

Isolates I2, I6, I7 were similar to the genus Penicillium, namely the formation of conidia, hyaline conidiophores, erect, containing monoverticillate peniles consisting of several metulae, phialides and catenulated conidia at the ends, phialosporus conidia, hyaline, round in shape (Watanabe, 2010). Isolate I8 was similar to the genus Microsporum in that conidia were not formed, hyphae were white or yellow with a glabrous to downy texture, branched with bamboo-like septa. Several types of Microsporum were also known as fungi that are pathogenic, especially on the skin (Indrawati \& Fakhrudin, 2016). Isolate I10 was similar to the genus Cladosporium, namely dark brown to brownish black colonies with powdery hyphae texture, branched and septate hyphae, with round to elliptical conidia and chain-shaped conidia collections.

\section{CONCLUSION}

This research has succeeded in isolating 6 genera of fungi (rhizosphere) which have been identified. Genus Rhizoctonia, Penicillium, and Papuplaspora were found to have resistance to $\mathrm{Pb}$ up to a concentration of 5,000 ppm, while Genus Microsporum and Cladosporium were not resistant. The genus Sclerotium has the ability to be resistant and not resistant to $\mathrm{Pb}$ up to a concentration of $5,000 \mathrm{ppm}$ which raised the suspicion that the isolates came from different species. Meanwhile, all isolates were found unable to grow at the high concentration tested, namely 10,000 ppm.

\section{REFERENCES}

Ahmad, R.Z. (2018). Mikoremediasi Menghilangkan Polusi Logam Berat pada Lahan Bekas Tambang untuk Lahan Peternakan. WARTAZOA 28 (1) : 041-050.

Aishwarya, S. Venkateswarulunagam. Netala, V.R. Tartte, V. (2017). Screening and Identification of Heavy Logam MetalTolerant Endophytic Fungi Lasiodiplodia theobromae from Boswella ovalifoliolata An Endemic Plant of Tirumala Hills. Asian Journal of Pharmaceutical and Clinical Research 10(3) : 488-491.

Amaral, J.H. Rezende, B. Quintana, S.M. Gerlach, R.F. Barbosa, F. Tanus-Santos, J.E. (2010). The Relationship betweenBlood and Serum Lead Levels in Peripartum Women and Their Respective Umbilical Cords. Basic \& Clinical Pharmocology \& Toxicology 107 (6) : 971-975.

Amatussalam, A. Abubacker, N.M. Rajendran, R.B. (2011). In situ Carica papaya Stem Matrix and Fusarium oxysporum (NCBT-156) Mediated Bioremediation of Chromium. Indian J. Exp. Biol. 49: 925-31. 
Anahid, S. Yaghmaei, S. Ghobadinejad, Z. (2011). Heavy Metal Tolerance Of Fungi. Sci Iran 18 :502-508.

Arunasri, P. Chalam, T.V. Reddy, N.P.E. Reddy, S.T. Reddy, R. (2011). Investigation on Fungicide Selectivity of Trichoderma spp and Sclerotium rolfsii (collar rot pathogen) in Crossandra. Int. J. Appl. Biol. Pharm. Technol 2: 290-293.

Asiriuwa, O.D. Ikhuoria, J.U. Ilor, E.G. (2013). Mycoremediation Potential Of Heavy Metals From Contaminated Soil. Bull Environ Pharmacol Life Sci 2 : 16-22.

Ed-har, A.A. Widyastuti, R. Djajakirana, G. (2017). Isolasi dan Identifikasi Mikroba Tanah Pendegradasi Selulosa dan Pektin dari Rhizosfer Aquilaria malasccensis. Buletin Tanah dan Lahan 1(1) : 58-64

Ekawati, A.Y. (2019). Optimalisasi Biosorpsi oleh Fungi Endofit Akar Tridax procumbens dari TanahTercemar Tembaga $(\mathrm{Cu})$ di Pertambangan Minyak, Bojonegoro Jawa Timur. [Skripsi]. Malang : Universitas Islam Negeri Maulana Malik Ibrahim Malang.

Fashola, M.O. Ngole-Jeme, V.M. Babola, O.O. (2016). Heavy Metal Pollution from Gold Mines : Environmental Effects and Bacterial Strategies for Ressistance. Int. J. Environ. Res. Public Health $13: 1047$.

Guimarães JB, Chambel L, Melzoch K, Pereira P, Tenreiro R. 2011 - Cladosporium sp. from phyloplane: a diversity evaluation on a Continental ecosystem. Mycosphere 2(3): 191-201.

Indrawati I, SD Fakhrudin. 2016. isolasi dan identifikasi jamur patogen pada air sumur dan air sungai di pemukiman warga desa karangwangi, cianjur, jawa barat. J Biodjati. 1 (1): 27-38.

Iram, S. Uzma. Gul. R.S. Ara. T. (2013a). Bioremediation of Heavy Metals Using Isolates of Filamentous Fungus Aspergillus fumigatus Collected from Polluted Soil of Kasur. Pakistan. Int Res J Biol Sci 2 : 1-6.

Iram, S. Waqar, K. Shuja, N. Perveen, K. Akhtar, I. Ahmad, I. (2013b). Tolerance Potential of Different Species of Aspergillus as Bioremediation Tool-Comparative Analysis. J Biodivers Environ Sci 3 : 1-10.

Jaiswal, S. 2011. Role of Rhizobacteria in Reduction of Arsenic Uptake by Plants: A Review. J. Bioremed. Biodegrad 2(4) : 1-5.

Kredics, L. Doczi, I. Antal, Z. Manczringer, L. (2001). Isolation and Characterization of Heavy Metal Resistant Mutants from Mycoparasitic Trichoderma strains.
Biological Control of Fungal and Bacterial Plant Pathogens 24(3) : 233-236.

Kurniawan, A. Mustikasari, D. (2019). Review: Mekanisme Akumulasi Logam Berat Di Ekosistem Pascatambang Timah. Jurnal Ilmu Lingkungan 17 (3): 408-415.

Kurniawan, A. Oedjijono. Tamad. Sulaeman, U. (2019). The Pattern of Heavy Metals Distribution in Time Chronosequence of ExTin Mining Ponds in Bangka Regency, Indonesia. Indonesian Journal of Chemistry 19(1):254-261.

Lotlikar, N.P. (2019). Physiological Response of Fungi from Marine Habitats to Heavy Metals. CSIR-National Institute of Oceanography.

Maini ZAN, Aribal KMJ, Narag RMA, Melad JKLT, Frejas JAD, Arriola LAM, Gulpeo PCG, Navarrete IA and Lopez CM. 2019. Lead (II) Tolerance and Uptake Capacities of Fungi Isolated from a Polluted Tributary in the Philippines. Applied Environmental Biotechnology 4(1) : 18-29. http://doi.org/10.26789/AEB.2019.01.004.

Olaniran, A.O. Boglobind, A. Pillay, B. (2013). Bioavaibility of Heavy Metals in Soil : Impact on Microbial Biodegradation of Organic Compounds and Possible Improvement Strategies. Int.J.Mol.Sci 14 : 10197-10228.

Rose, K.P. Devy, R. (2018). Heavy Metal Tolerance and Adaptability Assessment of Indigenous Filamentous Fungi Isolated from Industrial Wastewater and Sludge Samples. Journal of Basic and Applied Sciences 7 : 688-694.

Rossiana, N. Supriatun, T. Sumiarsa, D. Rescho, A.S. Dhahiyat, Y. (2015). Decreasing of Lead and Cadmium by Cladosporium and Albizia (Paraserianthes falcataria 1. nielsen) Mycorrhizal on Oil Sludge Phytoremediation. J Microbiol Exp 2(6) : 181184.

Sana, N. Shoaib, A. Javaid, A. (2015). Growth of A Soil-Borne Plant Pathogen Sclerotium rolfsii Under Chromium(Iii) Stress. Pak. J. Phytopathol 27(1): 55-6o.

Siddiquee, S. Aishah, S.N. Azad, S.A. Shafawati, S.N. Naher, L. (2013). Tolerance and Biosorption Capacity of Zn2+, $\mathrm{Pb2+}, \mathrm{Ni}_{3}+$ and $\mathrm{Cu}_{2}+$ by Filamentous Fungi (Trichoderma harzianum, T. aureoviride, and T. virens). Adv Biosci Biotechnol 4 :570583.

Suryati,T. (2017). Studi Fungi Mikoriza Arbuskula di Lahan Pasca Tambang Timah Kabupaten Bangka Tengah. Jurnal Teknologi Lingkungan 18(1): 45-53. 
Tian , D. Jiang, Z. Jiang, L. Su, M. Feng, Z. Zhang, L. Wang, S. Li, Z. Hu, S. (2018). A New Insight Into Lead (Ii) Tolerance of Environmental Fungi Based on A Study of Aspergillus niger and Penicillium oxalicu. Environmental Microbiology 21(1) : 471-479.

Watanabe, T. (2010). Pictorial Atlas of Soil and Seed Fungi Morphologies of Cultured Fungi and Key to Species : Third Edition. Florida : CRC Press

Wijaya, N. (2018). Kemampuan Isolat Jamur Asal BatangToru Tapanuli Selatan dalam
Menyerap Timbal. [Skripsi]. Medan : Universitas Sumatera Utara

Yang, T. Wang, X.Y. Wang, L.Y. Chen, M.L. Wang, J.H. (2016). Biological Cells in The Speciation Analysis of Heavy Metals. Analytical Methods 8(47) : 825-826.

Yanti, N. Samingan. Mudatsir. (2016). Uji Aktivitas Antifungi Ekstrak Etanol Gal Manjakani (Quercus infectoria) terhadap Candida albicans. Jurnal Ilmiah Mahasiswa Pendidikan Biologi 1(1) : 1-9. 